\title{
The Hodgepodge and Echelon of Citizens Participation in Environmental Law Enforcement of China:The 2015 Environmental Protection Law in Focus
}

\author{
Ayalew Abate Bishaw \\ The author has LLB from Haromaya University in Ethiopia and LLM from Alabama University law School of \\ USA. He has been a staff of Debre Markos University Law School, (www.dmu.et.edu.com) Ethiopia. \\ Currently he is SJD Candidate at Zhejiang University Guanghua Law School (http://net.zju.edu.con). Guanghua \\ Law School Zhejiang University 51 Zhejiang Road, Hangzhou Zhejiang Province, 310008, \\ China. He can be accessed at: Email: tsion.ayelam@yahoo.com, Mob: +86137354446506, +251918748526. He \\ takes all the responsibility in this work. Orcid Id: https://orcid.org/ooo-0002-6712-9849
}

\begin{abstract}
Among others, empowering the citizen in the environmental law enforcement was mentioned the reason for the 1989 environmental law reform in China for the 2015 environmental protection law adoption. The success of reform, however, has not been yet assessed and there is strong reason for scrutiny towel appreciate the nuts and hats of citizen participation in the environmental law enforcement. This article analysis the hodgepodge and echelon of citizen's participation in the 2015 environmental protection law of China with regard to enforcement by clarifying the definitions of law enforcement and citizen participation in light of recent international legal development and understanding. It explores the forms and types of citizen participation recognized by the law in an effort to identify the magnificent reforms of the new law and elucidate on the pitfalls. The existing literatures relating to citizen participation in environmental law enforcement are reviewed and doctrinal scrutiny was made on the environmental protection law. The finding confirms that citizen participation has got wide and onerous recognition, albeit their empowerment to take court action in the public interest has some stringent requirement and limitation. Citizen participation is crucial in environmental protection and is an evolving principle in environmental law enforcement. And hence additional effort to include citizens ${ }^{\text {ee }}$ right of court action in the environmental enforcement may, fortunately, upgrade the law to the highest scale and may attract a huge enforcement contribution from the public wing.
\end{abstract}

Keywords: Public interest, citizen participation, Environmental Law Enforcement, and citizen's rights, hodgepodge and echelon

DOI: $10.7176 / J L P G / 82-01$

\section{Introduction}

The environmental situation in China has been one of the most alarming ${ }^{1}$ that justifies citizen participation or involvement a necessity than complementary or just supplementary proper ${ }^{2}$. Besides participating the citizen in the environmental law enforcement is governed by the rule of law in the environmental decision making that signals accountability of the government which is an essence of the environmental social democracy-an essence of Chinese political philosophy. Social democracy is the basic principle that China has been aspiring to achieve in its political objective. Thus citizen participation in the environmental law enforcement is a corollary of Chinese government underpinning principle of 'Mobilizing the Masses for Social Change'.

Further citizen involvement in the environmental law enforcement has got international legal recognition, as significantly contributing in the environmental protection effort and meeting environmental protection objectives ${ }^{3}$.

\footnotetext{
${ }^{1}$ See Tyler Liu (2015) "China's Revision to the Environmental Protection Law: Challenges to Public Interest Litigation and Solutions for Increasing Public Participation and Transparency", Jonathan Kaiman in his expression has described China's Pollution as it resembles "nuclear winter". See Jonathan Kaiman, China's Toxic Pollution Resembles Nuclear Winter, Say Scientists, and the Guardian Feb. 25 2014. Link: http://www.theguardian.com/world/2014/feb/25/china.

Further as reported by Asian Development Bank, Asian Development Bank, Toward an Environmental Sustainable Future; Country Environmental Analysis of the People's Republic of China (may 28, 2012), less than 1\% of China's 500 largest cities met the World Health Organization's (WHO) air quality standards that shows the terrifying situation of China environment. Further it is reported also that the air and water quality in china is remarkably poor that causes health risk to much number of the population. These all proves the horrible situation that the people and the government are faced with regard to environmental problem.

See also Han Yong, Environmental Index: Measuring Up, News China (Oct.2015), http://www.newschinamag.com/magazine/measuring-up that shows in China less than ten percent of 161 Cities included in the national air quality monitoring system met national standards.

${ }^{2}$ Citizens' involvement in such environmental situation can't in any case be understood to be complementary to the government service but is necessity in that vibrant citizens need to be created made involved in the enforcement. It is more than complementary proper.

${ }^{3}$ See A Du Plessis (2008), Public Participation, Good Environmental Governance and Fulfillment of Environmental Rights, PER /PELJ 2008(11)2. It may be accessed from: https://repository.nwu.ac.za/bitstream/handle/10394/1885/2008x2x_6a_Du_Plessis_art.pdf?sequence=3 , Last Accessed on 18 Nov 2018 at 2:00 PM, P.2. See also Southern Africa Legal Information Institute (SAFLII) (2008), Public participation, Good Environmental Governance and fulfillment of Environmental rights" [2008] PER 12 as accessed from http://www.saflii.org/za/journals/PER/2008/12.html\#sdfootnote5anc , Last accessed on 17 Nov.2018
} 
And hence different countries have used to legally empower their citizen in environmental law enforcement albeit their range of participation and its successful history may vary from one to another. The range of citizen participation in the USA, for instance, has been known for its remarkable history of recorded achievements ${ }^{1}$. Whereas citizen participation in China has been still in the making triggering for the reform of the 1989 environmental law into 2015 basic environmental protection law ${ }^{2}$. Whether the 2015 environmental protection law has adequately incorporated citizen participation is the question of this undertaking. This question attracts scholars thought as on the eve of promulgation of the environmental protection proclamation Premier Li Keqiang snarled "We will resolutely declare war against pollution as we declared war against poverty", which implication is big as it nominally signals citizen mobilization towards environmental protection to meet environmental objectives that have been down-looked for decades in China. Particularly it logically stimulates the researcher to question whether the government legislative action allows citizens participation in the environmental protection law. This is because citizen participation is a fundamental element of environmental enforcement. Joseph Sax has condemned the following about citizen participation as his exhibitionism stated: ${ }^{3}$

'So long as....discretionary decisions of governmental agencies are immunized from citizen challenge in the courtroom, government officials will retain their practical monopoly over the business of implementing the public interest. It is extraordinary for the government to take the position that citizens who have the most direct stakeshould have no significant role to play in the determination of their environmental destiny. Is pursuit of the public interest to be the exclusive preserve of a professional bureaucracy?'

Since recently China has also pledged the world to lodge a war against environmental problems and climate change as it has done for decades against poverty. This leads to the enthusiastic expectation of citizen's participation in environmental law enforcement. Among the reforming reasons, public participation was mentioned there before.

Since recently citizen involvement in the environmental law enforcement has taken on a new thrust and considerable legislative activities have been done for determining the role of citizens in the environmental law enforcement ${ }^{4}$. Almost by all the governments in the world, the role of citizens in environmental law enforcement has got wide recognition ${ }^{5}$. And hence at least ideally there is no hostility to allowing ordinary citizens to assist in the environmental laws enforcement ${ }^{6}$.

The purpose of this article is, therefore, to make legal analyses on the environmental protection law of China to determine the range of citizen participation in environmental law enforcement and reflect on its approach relating to citizens role in the enforcement. So as to make the aforementioned objective the manuscript is prearranged with three sections excluding this introductory remark.

The first section conspicuously describes the 2015 environmental protection law of the People's Republic of China. The structure and the purpose of this law will be clearly marked out so as to provide basic insight about its objectives and fundamental guiding principles. This will provide readers understand the law and real subject areas of the articles confinement.

The second section dwells on elaborating the general notion of citizen participation in environmental law enforcement. It briefly defines enforcement and citizen participation in environmental law enforcement, elaborate hodgepodge, and forms of participation including the benefits of citizen participation. This section will help readers to get the theoretical underpinnings of citizen participation in environmental law enforcement.

The third section is about the analyses of hodgepodge and echelon of citizen participation as incorporated in the environmental law of China. It has two subsections: the participation of citizens in the administration and citizen participation in the judiciary. The third section deals on the major tribulations of the environmental protection law of China, 2015 concerning citizen participation in environmental law enforcement while the last

\footnotetext{
1 David Mossop, Citizen Suits: Tools for Improving Compliance with Environmental Laws http://citeseerx.ist.psu.edu/viewdoc/download?doi=10.1.1.519.8696\&rep=rep1\&type=pdf, last Accessed on 17 Nov 2018 at 8:51

2 Tyler Liu (2015), China's Revision to the Environmental Protection Law: Challenges to Public Interest Litigation and Solutions for Increasing Public Participation and Transparency, Journal of Energy and Environmental Law , p. 60

${ }^{3}$ See Joseph Sax (Sax 1971,P.10) as cited by David Mossop, Citizen Suits- Tools For Improving Compliance with Environmental Laws, p.1

${ }^{4}$ See A Du Plessis (2008), Public Participation, Good Environmental Governance and Fulfillment of Environmental Rights, PER /PELJ 2008(11)2. It may be from: https://repository.nwu.ac.za/bitstream/handle/10394/1885/2008x2x_6a_Du_Plessis_art.pdf?sequence=3, Last Accessed on 18 Nov 2018 at 2:00 PM, P.2. See also Southern Africa Legal Information Institute (SAFLII) (2008), "Public participation, Good Environmental Governance and fulfillment of Environmental rights" [2008] PER 12 as accessed http://www.saflii.org/za/journals/PER/2008/12.html\#sdfootnote5anc, Last accessed on 17 Nov.2018

${ }^{5}$ See Economic Commission for Latin America and the Caribbean (ECLAC), Access to information, participation and justice in environmental matters in Latin America and the Caribbean: towards achievement of the 2030 Agenda for Sustainable Development (LC/TS.2017/83), Santiago, 2018. Chapter one of this research shows the wide in range recognition of the right to public participation in the environmental law enforcement among the international community that includes the government and non government organizations. The chapter is entitled as : Access to information, participation and justice in environmental matters at the international level. The international scenario is well discussed to the level of confirmation that public participation in the environmental law enforcement has got wide and global recognition.

${ }^{6}$ Some states confer full right to its citizens to involve in the environmental law enforcement while others limit it exceptionally. And hence there is variation at practical level.
} 
part illustrates concluding remarks and recommendations.

\section{Brief Explanation of the Environmental Protection Law of People's Republic of China, 2015}

The Environmental Protection Law of the People's Republic of China (2014 Revision) hereinafter referred as the 'environmental protection law' is made by the order of the president of the People's Republic of China (Xi Jinping) in 2014. It was revised and adopted at the $8^{\text {th }}$ session of the Standing Committee of the $12^{\text {th }}$ National Congress of the People's Republic of China on April 24, 2014. It has come in to force nearly after a year of its issuance, since January 1, 2015. It is comprehensive legislation containing about seven chapters: chapter one: general provisions, chapter two supervision and administration, chapter three environmental protection and improvement, chapter four prevention and control of pollution and other public nuisances, chapter five information disclosure and public engagement, chapter six legal ability, and chapter seven is about supplementary provisions. The total number of articles .....As discussing each of the chapters doesn't fall within the purpose, they are not discussed. This discussion focuses only on the general provisions so as to give some insight about its scope, purpose and basic guiding principles.

Its application is all over the territory and sea areas under the jurisdiction of China ${ }^{1}$. So it applies over all the provinces $^{2}$. In this law environment is defined broadly that include: "the entirety of all natural elements and artificial transformed natural elements that affect the survival and development of human beings, including but not limited to air, water, sea, land, minerals, forests, grasslands, wetlands, wildlife, natural and cultural relics, natural reserves, scenic spots, historic sites and urban and rural areas" It is so broad definition that recognizes to include all elements of the ecosystem, its interaction, and interdependent.

The purpose of the law as enshrined in article one includes: for protecting and improving the environment, preventing and controlling pollution and other public nuisances, safeguarding public health, promoting ecological civilization, and enhancing sustainable economic and social development." ${ }^{\prime 3}$ The objective clause is fascinating covering fundamental environmental initiatives such as prevention of pollution, controlling pollution, protecting the environment, improving the environment already degraded and injured, controlling public nuisance, safeguarding public health and safety, enhancing sustainable economic and social development which are really fascinating and enthusiastic. The environmental protection law further pledges that protecting the environment is a fundamental national policy in the State. The protection effort shall adhere to the principles of giving priority to protection, focusing on prevention, conducting comprehensive treatment, engaging the general public and enforcing accountability for damage ${ }^{4}$. Citizen participation has been mentioned as one of the rationales for the amendment of 1989 environmental law ${ }^{5}$. From this one shall notice that engaging the general public is one of the fundamental principles of environmental protection law in China. What is the range of their participation and how their role is recognized in this law are the basic questions to be explored in this article.

\section{The Notion of Citizen Participation in the Environmental Law Enforcement}

In this article environmental law enforcement refers to: "the range of procedures and actions employed by a State, its competent authorities and agencies to ensure that organizations or persons, potentially failing to comply with environmental laws or regulations, can be brought or returned into compliance and/or punished through civil, administrative or criminal action." And citizen participation otherwise called public participation denotes the legal empowerment of citizens ${ }^{7}$ and the range of their legal engagement in such enforcement processes excluding the criminal actions.

Law enforcement is a coordinated effort run by both the government and the people. It is not one shot and single action left for the government wing only. Though the government is an organized and institutionally authorized body in the law enforcement, still citizen's role shall be underscored in the success of law enforcement. This is because citizens' participation plays an extensive supplemental role in government efforts ${ }^{8}$. Especially for its effectiveness, it requires active participation from the public wing. Public participation is one of the central

\footnotetext{
${ }^{1}$ See Article 3 of the Environmental Protection Law.

${ }^{2}$ Ibid

${ }^{3}$ Ibid See Article 1

${ }^{4}$ Ibid See Article 5

${ }^{5}$ See Wang Canfa (2007) Chinese Environmental Law Enforcement: Current Deficiencies and Suggested Reforms, Vermont Journal of Environmental Law [vol. 8. P.160-193. He has suggested that a procedure shall be adopted for the full citizens' participation. The article may be accessed also from: http://vjel.vermontlaw.edu/files/2013/07/Chinese-Environmental-Law-Enforcement.pdf

${ }^{6}$ UNEP (2001), Enforcement of Environmental Law Good Practices from Africa, Central Asia, ASEAN Countries and china, https://wedocs.unep.org/bitstream/handle/20.500.11822/9968/enforcement-environmental-laws.pdf?sequence=1\&isAllowed=y, Last accessed on 18 Nov 2018. PP.

${ }^{7}$ See Alastair R. Lucas, Legal Foundations for Public Participation in Environmental Decision Making, 16 Nat. Resources J. 73 (1976). Available at: http://digitalrepository.unm.edu/nrj/vol16/iss1/6 P. 63-102

${ }^{8}$ Ngozi F. Stewart, A Roadmap for the Effective Enforcement of Environmental Laws in Nigeria, National Environmental Law Review 2011:

2 http://classic.austlii.edu.au/au/journals/NatEnvLawRw/2011/34.pdf, Last Accessed on 17 Nov 2018, p.49
} 
principles of environmental law enforcement ${ }^{1}$. And whatsoever form the government political ideology (liberal, social or developmental) may it adopt or whichever economic wealth (resource) may the government have accumulated, the essentiality of citizen engagement is more than a just in the decision making and law enforcement ${ }^{2}$. As a result in the $21^{\text {st }}$-century public participation in the decision making and law enforcement had got legal recognition by both international and national legislation ${ }^{3}$. The Rio declaration ${ }^{4}$ principle 10 is the first and the most significant code to give fundamental articulation and global dimension for public participation ${ }^{5}$. It stated that:

"Environmental issues are best handled with the participation of the all concerned citizens at the relevant level. At the national level, each individual shall have appropriate access to information concerning the environment that held by the public authorities including information on hazardous materials and activities in their communities, and the opportunity to participate in the decision making process."

As described by Wang Xi public participation in the environmental enforcement could mean allowing, encouraging and supporting the public to actively participate in environmental decision-making and management, evaluate and supervise the relevant activities of government in order to realize public interests ${ }^{7}$.

Public participation can take different forms in environmental law enforcement ${ }^{8}$. The public may create a pressure group to exert influence on the government environmental decision making, can act as a member in the environmental advisory council, and may form also environmental amicus curie to litigate before courts for sake of environmental interest, or may act as spokesmen too. It may be operated through individuals, representative groups and/or public interest groups just it can also be done in other aspects.

The benefit of citizen participation can be put summarized as it fosters public trust to environmental decision making, environmental governance and transparency, environmental accountability, and entertainment of alternative views, environmental democracy, and others within the arm of the government so as to ensure public interest ${ }^{9}$. It gives the opportunity to influence environmental public decision making and ensures its enforcement ${ }^{10}$.

\section{The Range of Citizens Involvement in the $\mathbf{2 0 1 5}$ Environmental Protection Law of China}

Public participation avenues in environmental enforcement are many and varied as described above ${ }^{11}$. Some countries and some environmental activities require special expertise while others demand common sense and energy $^{12}$. Some participation involves the citizens to work alongside the government while others place them on the shoes of the government ${ }^{13}$. Still, others call for citizens to oppose the government's activities while some require extensive financial expenditures or time ${ }^{14}$. Some states provide citizens the right to challenge a wide range of public and private activities that injure public interest while others provide much more limited right to protect some specific ecologically valuable areas etc. These mechanisms indeed contribute to effectuate compliance with environmental control. And this section is meant to identify the range of citizens' involvement in the environmental protection law of China.

For the sake of clarity and simplicity citizen involvement can be categorized and discussed under two taxonomies in Chinese environmental protection law: citizen involvement in the administration and citizen

\footnotetext{
${ }^{1}$ The three pillar principles in the environmental law enforcement includes: The right to environmental information, the right to public participation and the right of access to environmental justice. They are fundamental principles in the environmental decision making and law enforcement as enshrined in Aarhus Convention. See MÜLLEROVÁ, H. et al. Public Participation in Environmental Decision-Making: Implementation of the Aarhus Convention. Praha: Ústav státu a práva AV ČR, 2013, 255 s. ISBN 978-80-87439-14-2., It can be accessed from: https://www.ilaw.cas.cz/upload/web/files/books/aarhus fin.pdf, Last Accessed on 17 Nov 2018. P. 2

${ }^{2}$ P. Lee Lakrishnan, Public Participation in Decision Making, Cochin University Law Review; accessed at www.dspace.cusat.ac on 18 Sep 2018 at $11: 24$

${ }^{3}$ See Nancy P. Spyke, Public Participation in Environmental Decision Making at the New Millennium: Structuring New Spheres of Public Influence, 26 B.C. Envtl. Aff. L. Rev. 263 (1999), P.263-270. http://lawdigitalcommons.bc.edu/ealr/vol26/iss2/2

${ }^{4}$ Rio Declaration on the Environment and Development, 12 August 1992, UN GA, A/CONF. 151/26 (Rio Declaration)

${ }^{5} \mathrm{Ibid}$

${ }^{6}$ Ibid and see also Jonas Ebbesson (2011), Public Participation and Privatization in Environmental Matters: An Assessment of the Aarhus Convention, Erasmus Law Review, Volume 4, Issue 2 (2011) https:/www.elevenjournals.com/tijdschrift/ELR/2011/2/ELR 22102671_2011_004_002_003.pdf Last accessed on 18 Nov 2018

${ }^{7}$ Xi Wang (2017). A Study on China's System of Public Participation in Environmental Protection ----Taking Haikou's "Two Constructions" for Example. IOP Conference Series: Earth and Environmental Science. 51. 012012. 10.1088/1742-6596/51/1/012012.

${ }^{8}$ P. Lee Lakrishnan, Public Participation in Decision Making, Cochin University Law Review; accessed at www.dspace.cusat.ac on 18 Sep 2018 at $11: 24$ p. 1

${ }^{9}$ Ibid and see also Lang, H. (2014). Public participation in environmental decision-making in China: Towards an ecosystem approach [S.1.]: [S.n.] PP. 13. See also World Bank (2002), Citizen Participation in Central and Eastern Europe: A Catalyst for Reform and A Monitor of Progress http://siteresources.worldbank.org/INTBELARUS/Resources/eng.pdf

${ }^{10}$ Nancy P. Spyke, Public Participation in Environmental Decision Making at the New Millennium: Structuring New Spheres of Public Influence, 26 B.C. Envtl. Aff. L. Rev. 263 (1999), P.263-313. http://lawdigitalcommons.bc.edu/ealr/vol26/iss2/2

${ }^{11}$ See also Robert E. and Dobbins J. (2006), the role of citizens in the environmental law enforcement, Environmental Law Institute USA. It can be accessed from $h t t p: / / w w w . i n e c e . o r g$ too. p. 3

${ }^{12}$ Ibid

${ }^{13}$ Ibid

${ }^{14}$ Ibid
} 
involvement in the judiciary. ${ }^{l}$ Involvement in the administration refers to be active on the actions and omissions that the government administrative organs are supposed to do by law or by state delegation and call for them to environmental compliance. For instance, the administrative body naturally has the set of actions to carry out to ensure compliance with environmental requirements such as the issuance of the permit, cancellation of a permit, consideration of EIA and monetary punishment ${ }^{2}$. Therefore citizen's administrative enforcement is meant to take part in such types of government administrative requirements.

Participation in the judiciary refers to citizen's empowerment by law to take court action either on the government as it fails to discharge its basic functions related to the environment or against the environmental law violators. This may include a court action for prompt regulatory action; citizen mounting of court enforcement actions against violators when government lacks the desire or the ability to prosecute ${ }^{3}$.

\subsection{Citizens Involvement in the Administration/ Bureaucracy}

a) Promoting Environmental Knowledge to Use in the Environmental Protection Law Enforcement In an effort to protect the environment, citizens in China are obliged to raise their environmental knowledge, adopt low carbon and economical lifestyles and conscientiously fulfill their obligation towards protecting the environment ${ }^{4}$. In China, environmental protection is the legal obligation of all the individuals and entities and it is not the duty left only to the government. Under Article 6 the Environmental Protection Law stipulates that "all entities and individuals shall have the obligation to protect the environment" ${ }^{\text {"T }}$. The law in particular addresses that both the government and citizen are duty bound to not only protect the environment but also promote their knowledge to best adapt the economic style that foster environmental protection (towards green economic development model). It presupposes that environmental protection demands knowledge about the environment and hence all entities and individuals shall promote the kind of environmental knowledge required to show off in the fight against environmental disaster.

The mechanism, source and kind of knowledge that citizens require in the environmental protection endeavor, in fact, are not specifically addressed in the law and is an activity left to citizens. Still, however, government environmental information could be one source of knowledge as described in article nine ${ }^{6}$. This implies that the government has otherwise obligated to create a favorable atmosphere for citizens to obtain environmental knowledge $^{7}$. Among others, for instance, it is the government duty to cultivate student's awareness through the school curriculum ${ }^{8}$.

\section{b) Reporting}

The other activity citizens are empowered to engage in environmental enforcement so as to discharge their responsibility in the environmental protection is to report what they discovered as ecological damage and any environmental damage to the environmental protection administrative departments or other departments with environmental protection supervision and administration functions ${ }^{9}$.

They are empowered to report against the act of both government and individual acts that bring damage to the environment. They are not required basically to make an analysis of the environmental law as to whether the environmental damaged sustained is because of the violation of environmental law. The only condition set is whether they have observed any damage to the environment. This responsibility, in fact, includes reporting to the higher level authorities or supervisory authorities against the failure by the environmental administrative departments ${ }^{10}$. The right of citizens thus is not limited to private environmental failure and includes a failure from

\footnotetext{
${ }^{1}$ The environmental protection law doesn't clearly mark out citizen's participation as administrative and judicial. But from the nature of activity we can understand that most activities citizens are permitted to involve are administrative while only few are judicial.

${ }^{2}$ UNEP (2014), Enforcement of Environmental Law: Good Practices from Africa, Central Asia, ASEAN Countries and China, pp 14-16; can be accessed from www.unep.org last accessed 9/13/2018@11:20

${ }^{3}$ Roberts E. and Dobbins J.(2006); The Role of Citizen in Environmental Enforcement, Environmental Law Institute 1616 P Street NW Washington DC 20036, USA. It can be accessed also from $h t t p: / / w w w . i n e c e . o r g / 2^{\text {nd }} v o l l / R o b e r t s . h t m(10 f 37) 9 / 19 / 2006$

${ }^{4}$ See, article 60 f Environmental Protection Law of the People's Republic of China (2014 Revision), order of the president of the People's Republic of China Number Nine (9). From this we can understand that the law has made acquiring environmental knowledge legal obligation as strategy to involve the mass from grass root level.

${ }^{5}$ Ibid

${ }^{6}$ Article 9 states that the people's government at all levels shall strengthen the publicity and dissemination of information on environmental protection, encourage basic level self governing organizations of the masses, social organizations and environmental protection volunteers to conduct publicity of the environmental protection laws and regulations and environmental protection knowledge, and create a favorable atmosphere for environmental protection.

Educative administrative departments and schools shall include environmental protection knowledge in school education to cultivate student's awareness of environmental protection. News media shall publicize environmental protection laws and regulations and environmental protection knowledge, and oversee environment-related illegal acts.

${ }^{7}$ Ibid

${ }^{8}$ Ibid

${ }^{9}$ See Article 57 of the environmental protection law

${ }^{10} \mathrm{Ibid}$, See second paragraph of the Article 57
} 
the public bureaucracy ${ }^{1}$ too.

As Roberts E. and Dobbins J. rightly described Citizens know the country's land and other natural attributes more intimately than the government ever will. Their number makes pervasive than the largest government agency. And because citizens work, play and travel in the environment each has a personal stake in its beauty, health, and permanence $^{2}$. This situation makes citizens in a unique position to report what they have encountered as to the environment for the concerned agency or challenge anti-environmental practices.

In fact, there is no guarantee that makes the agency receiving the information to act on the bases of citizen report. Citizens' don't have extended right to supervise the government agency work and bring an action against the government department either to the adjudicative or judicial organ.

c) Citizens Action of Cooperation and Solicit Opinion

In the PR China, the other range of area citizens is to involve in the environmental law enforcement is to cooperate in the implementation of environmental protection measures. Cooperation is a fundamental environmental law principle enshrined in many international treaties ${ }^{3}$. The principle is reflected in many treaties and other international acts and is supported also by state practice, particularly in relation to hazardous activities and emergencies. Still, however, the principle applies more of at an international and state's level than individual as expressed. In China, citizens are mandated to co-operate the government in its effort to prevent the environment ${ }^{4}$. Further, the public at large is empowered to solicit their opinion on environmental impact assessment (EIA) $)^{5}$. As per this article, citizens are empowered to solicit their opinion and have the right to consultation/participation. Yet whether the citizen has right of judicial intervention as amicus curiae and interested third party in the litigation process is not clear and is very unlikely to be operational. Further, whether the citizens are empowered to reject the project that their opinion is not solicited or whether they can make project approval rejected provided the project has a significant impact on their social, economic, environmental wellbeing is not settled and in fact unlikely to be operational. The mechanisms for doing so are not set forth. This is because the law has gaps in this respect. For clarity putting the provision may worth little. It stated as: "after receiving the environmental impact report for a construction project, the department approving the environmental impact assessment documents for construction projects shall disclose the full text of the report, except the part involving any state secret or trade secret, and it if discovers that public opinions have not been fully solicited regarding the project, the department shall order the construction employer to solicit public opinion."

\section{d) Participate in the Government Regulatory or Enforcement Action}

As described above in the introduction part, citizen participation in the environmental law enforcement enlists/includes, among others, complementing government agency regulatory and enforcement efforts. This includes commenting of the government regulations and permits, intervening in the government environmental suit against the polluter, filing non-binding amicus curiae etc.

The PR of China another environmental legal framework in this respect has mandated the citizens to participate in the public hearing at environmental impact assessment (EIA) ${ }^{6}$. Article 13 of Prevention and Control of Water Pollution Law 1996 stated as: 'An environmental impact statement shall contain comments and suggestions of the units and residents in the place where the construction project is located.'

Environmental Impact Assessment 2003 (amended in 2016) has specially provided for a hearing procedure for related issues that greatly impact the public. In order to enforce this procedure, former State Environmental Protection Administration specifically formulated the Interim Measures for Public Participation in Environmental Impact Assessment in 2006, providing concrete methods for public participation in environmental impact assessment. This shows that citizen involvement in the government enforcement proceeding of EIA is recognized. Further in a very clear manner Article 47 of Administrative License Law 2007 has shown the range of involvement of citizens in the regulatory and permits system by stating as:

'Where an administrative license is of direct significance to the interests of the applicant or others before the administrative organ makes a decision about the administrative license, it shall inform the applicant or the interested party of the right to request for a hearing. Where the applicant or interested party applies for a hearing

\footnotetext{
Ibid

${ }^{2}$ See Roberts E. and Dobbins J.; the Role of the Citizen in Environmental Enforcement, Environmental Law Institute, 1616 P Street N.W. WASHINGTON DC 20036, USA. It can also be accessed from http://www.inece.org/2ndvoll /roberts.htm/9/19/2006 p.1, This can be also accessed from: S Casey-Lefkowitz, JW Futrell, J Austin and S Bass, 'The evolving role of citizens in environmental enforcement', Paper delivered at the Fourth International Conference on Environmental Compliance and Enforcement, available at: http://www.inece.org/4thvol1/ftrell.pdf. See also Environmental Law Institute, the Role of the Citizen in Environmental Enforcement from: https://www.eli.org/

3 See Rengeling, H.W., the Principle of Cooperation in Environmental Law https://inis.iaea.org/search/search.aspx?orig_q=RN:20064483.

See also International Environmental Principles as can be https://edisciplinas.usp.br/pluginfile.php/520713/mod_resource/content/1/Cap.3_International\%20Environmental\%20Law\%20\%281\%29.pdf PP.50-90. Last Accessed on 20 Nov. 2018

${ }^{4}$ See Article 38 of the Environmental Protection Law 2015

${ }^{5}$ See article 56 of the Environmental Protection Law 2015

${ }^{6}$ Ibid as illustrated in article 56 and 57.
} 
within 5 days from the day when it is informed of such right, the administrative organ shall organize a hearing within 20 days. The applicant and interested party shall not pay for the expenses arising from the administrative organ's organization of the hearing.'

But there is no clear provision that shows citizens involvement in the government enforcement suits in the environmental protection law. From this, the range of citizen involvement can be understood to be very wide ranging from the awareness creation to adopt the environment-friendly and carbon free or low economic lifestyle. And further, there are varies kinds of citizen involvements in environmental law enforcement as discussed above.

\section{e) Information Disclosure and Public Engagement}

The right to information is the basic pre-requisite for citizens to environmental law enforcement. As per article 53 and 54 of the environmental protection, the citizens shall have the right to obtain information from the public administration bodies entrusted with responsibility. The public administration is duty bound to provide information to the public including the record of environmental violations by enterprises, public institutions, and others including the names of the violators. The enterprises are also legally required to disclose environmental information to the public ${ }^{2}$. Whether citizens have to monitor is not, however, clear. As citizens are in a position to identify areas in need of further regulation and are believed to be uniquely qualified for such a role empowering them would have a better effect than allowing as mere information recipient. Disclosing the violators to the public is really important enforcement tool as the public can take its own measure against the violator by affecting the reputation and rebelling against their product ${ }^{3}$. Therefore in general information is the major tool in environmental enforcement and citizens are given with the right to get the required information and hold important position to play their own role.

\subsection{Citizens Judicial Involvement-Public Interest Environmental Litigation}

By citizens judicial involvement it meant the legal status of citizens in the environmental protection law of China to recourse to court in an effort to enforce environmental laws. It may be either an effort to challenge government actions or failures to manage or regulate the environment or suit against private entities to enjoin the government activity on public or private violations. And hence in this section, an attempt is made to analysis on the environmental protection law of China as to the kind of legal arrangement made for judicial environmental enforcement to citizens.

As remarkably quoted in the introduction part of this article, "So long as....discretionary decisions of governmental agencies are immunized from citizen challenge in the courtroom, government officials will retain their practical monopoly over the business of implementing the public interest. It is extraordinary for the government to take the position that citizens who have the most direct stake-should have no significant role to play in the determination of their environmental destiny. Is pursuit of the public interest to be the exclusive preserve of a professional bureaucracy? ${ }^{4,}$

And hence it is as clear and simple as counting the alphabet that, citizens shall have the stake to initiate lawsuits to present and vindicate their position in the courtroom over environmental management controversies. Participating citizens over administrative issues, evident that citizens have a critical role to play in environmental protection and hence it signals the government's commitment to environmental protection.

To the opposite refusing the citizens their right to initiate lawsuits amounts to decide over the fate of their environmental destiny that gestures practical monopoly over the public interest. In China, however, the environmental protection law incorporates public interest environmental litigation unlike the previous legal framework, 1989.

Public interest environmental litigation is environmental enforcement tool that many countries adopt in their legal system in an effort to achieve environmental protection objectives ${ }^{5}$. It has a significant contribution to the environmental governance and meeting the environmental protection objectives ${ }^{6}$. It can be run by public-spirited citizens and/or by organized social groups. It is a crucial tool in the environmental litigation that most environmental legal frameworks adopt ${ }^{7}$. In China, the law recognizes the organized form of environmental public interest litigation as can be understood from article 57 . Citizens are given a wide range of opportunity to legally engage in environmental protection efforts. In this case, however, there is no way at private level to recourse to court action and the law has chosen the litigation aspect to be run by rather a group of citizens referred as "social organizations 8 ". Therefore the kind of environmental litigation adopted at citizen level in China is in an organized

\footnotetext{
${ }^{1}$ Zhu Xiao (2011), Environmental Law, China Environmental Science Press $1^{\text {st }}$ ed. P.104

${ }^{2}$ See the Environmental Protection Law Article 54 and 55.

${ }^{3} \mathrm{Ibid}$, See Article 54 last paragraph.

${ }^{4}$ Supra note 5

${ }^{5}$ See Ayalew Abate Bishaw (2015), Public Interest Environmental Litigation (PIEL) Under Ethiopian Law, www.theinternationaljournal.org RJSSM: Volume: 05, Number: 7, November 2015 PP. 70-91.

${ }^{6}$ Ibid

${ }^{7}$ Ibid

${ }^{8}$ Ibid
} 
form. And the social organizations that are supposed to recourse for court action, as clearly stipulated, are expected to satisfy the following legal requirements ${ }^{1}$ :

A). Registration at or above district city before civil affairs department

$B)$. Environmental protection Work Experience of five years and no record of law violation

C). It shall not seek economic benefit from the litigation instituted and

D). the action affecting the environment shall be of not private but public interest.

Pursuant to this article the subject of the conduct that violates the environmental law and cause pollution or ecological damage is not specified. And hence one can allege that the provision allows the social organization to bring court action even against the government. As is clear from the wording of this provision "for an act polluting environment or causing ecological damage in violation of public interest" the social organization can act against all the subjects of law in its court action for the environmental protection. Still, however, the law is not clear about whether the social organization can bring an administrative action or can bring regulatory actions against the government when government inaction causes environmental damage. So its applicability looks very limited in that damage shall sustain the proof of which on the environmental law is very intricate because of the fact it takes time and costly. The act as expressed is not also clear whether it takes ex-ante or post. The procedural requirements citizens shall fulfill to form a social organization and licensed are not clear and simple (particularly the requirement specified in b). Whether the act includes government legislation that has constitutionality and review issues is not also clear. Who covers the cost of litigation and other important preconditions of litigation are not addressed. Public-spirited individuals are not empowered to bring a court action against the violators.

\section{Concluding Remarks and Some Recommendations}

Citizen participation in environmental law enforcement is an important impetus at the present time that complements the government role in the public interest. Accordingly, international legal instruments such as Rio declaration and various domestic laws have recognized it as a fundamental principle of law. There are many forms of citizen participation in environmental law enforcement to contribute to its protection.

In the People's Republic of China, citizen participation had been one of the causes of the environmental law reform in 2015. As a result since 2015 citizens' involvement in the environmental law enforcement has got legislative shore up. And the legislature has in bold owed to citizens grand responsibility to protect the environment.

The ranges of citizen participation in the environmental protection law are various. As per the environmental law, they may be classified into two: citizen participation in the administrative bureaucracy and citizen participation in the judiciary. The participation of the citizens in the administrative includes awareness creation (promoting knowledge), reporting, and solicitation of opinions, participating in regulatory activities and information disclosure and public engagement. The citizen participation in the judicial recourse includes forming an association to take court action against the violator. The public interest environmental provision, though encouraging, is somehow narrow in scope and unclear. It needs further interpretation and clarification.

In general, the environmental protection law of 2015 has met its objective of engaging the citizen in environmental protection via recognizing different modalities. To be more full-fledged it may consider granting the broad right of standing for public-spirited individuals for taking environmental court action against the violator including the government. It may also relax the public interest environmental litigation requirements so that organized bodies can bring environmental cases for the public interest.

\section{References:}

1. Alastair R. Lucas, Legal foundations for Public Participation in Environmental Decision Making 197616 Natural Resources Journal 73(1976); Available at http://digitalrepository.unm.edu/nrj/vol16/iss1/6

2. Asian Development Bank (May 28, 2012), Asian Development Bank, Toward an Environmental Sustainable Future; Country Environmental Analysis of the People's Republic of China.

3. Environmental Protection Law of the People's Republic of China (2014 Revision), the order of the president of the People's Republic of China Number nine.

4. James R. May (2004), the Availability of State Environmental Citizen Suits, 18SPG Natural Resource and Environment Journal Vol.32 No.2 American Bar Association; P. 1-11

5. Jonathan Kaiman, China's Toxic Pollution Resembles Nuclear Winter, Say Scientists, and the Guardian Feb. 25, 2014. Link: http://www.theguardian.com/world/2014/feb/25/china.

6. Joseph Sax (Sax 1971), Citizen Suits- Tools For Improving Compliance with Environmental Laws, p.1

7. Han Yong, Environmental Index: Measuring Up, News China (Oct.2015), http://www.newschinamag.com/magazine/measuring-up

8. Mark A Ryan (2017), Clean Water Act Citizen Suits: What the Numbers Tell Us, Natural Resource and Environment Journal Volume 32 Number 2; American Bar Association. 
9. Robert E. and Dobbins J. (2006), the role of citizens in the environmental law enforcement, Environmental Law Institute USA. It can be accessed from $h t t p: / / w w w . i n e c e . o r g$ too. p. 3

10. Roberts E. and Dobbins J.; the Role of the Citizen in Environmental Enforcement, Environmental Law Institute, 1616 P Street N.W. WASHINGTON DC 20036, USA. It can also be accessed from http://www.inece.org/2ndvoll /Roberts.htm/9/19/2006 p.1

11. Tyler Liu (2015), China's Revision to the Environmental Protection Law: Challenges to Public Interest Litigation and Solutions for Increasing Public Participation and Transparency, Journal of Energy and Environmental Law, p. 60

12. Zhu Xiao (2011), Environmental Law, China Environmental Science Press p.104 